\title{
Pentingnya Pendidikan Ekonomi Informal Dalam Mewujudkan Perilaku Ekonomi Mahasiswa Yang Rasional
}

\author{
Inanna \\ Pendidikan Ekonomi Universitas Negeri Makassar \\ Email: inanna@unm.ac.id
}

\begin{abstract}
This study aims to determine the effect of education provided by parents in realizing rational economic behavior of students. The method used is a quantitative approach with a population of 659 students and a sample of 70 students. Data collection techniques used were observation, questionnaires and documentation. The data analysis technique used is simple linear regression analysis. The results showed that informal economic education had an influence in realizing rational economic behavior in the students of economic education in Makassar State University.
\end{abstract}

Keywords: Informal Economy Education; Economic Behavior; Rationality

\begin{abstract}
Abstrak. Penelitian ini bertujuan untuk mengetahui pengaruh pendidikan yang diberikan orang tua dalam mewujudkan perilaku ekonomi mahasiswa yang rasional. Metode yang digunakan yaitu pendekatan kuantitatif dengan populasi berjumlah 659 mahasiswa dan sampel sebanyak 70 mahasiswa. Teknik pengumpulan data yang digunakan adalah observasi, angket dan dokumentasi. Teknik analisis data yang digunakan adalah analisis regresi linear sederhana. Hasil penelitian menunjukkan bahwa pendidikan ekonomi informal mempunyai pengaruh dalam mewujudkan perilaku ekonomi yang rasional pada mahasiswa pendidikan ekonomi Universitas Negeri Makassar.
\end{abstract}

Kata kunci: Pendidikan Ekonomi Informal; Perilaku Ekonomi; Rasionalitas

\section{PENDAHULUAN}

Dinamika permasalahan ekonomi berkembang baik dalam bidang produksi, konsumsi maupun distribusi. Salah satu permasalahan pokok yang sering dijumpai adalah aktivitas konsumsi serta pemenuhan kebutuhan sehari hari dalam lingkungan keluarga. Hal ini masuk dalam kajian pendidikan informal, yang berlangsung secara terus menerus sapanjang hayat untuk kepentingan hidupnya dimasa yang akan datang (Požgaj, 2008).

Menjawab tantangan ini, maka proses pendidikan ekonomi dalam keluarga memegang peran penting dalam mewujudkan perilaku ekonomi anggota keluarga yang rasional. Keluarga mempunyai pengaruh pada pola tingkah laku anak-anak, lingkungan keluarga, baik besar atau kecil mempunyai pengaruh pada pertumbuhan dan perkembangan anak, perilaku ini antara lain, dalam bentuk pola asuh, gaya dan sikap orang tua, Mintarti $(2014 ; 167)$. Pendidikan dalam hal ini, merupakan proses sosio-kultural yang bertujuan untuk membawa peserta didik memahami dirinya sendiri, orang lain, maupun lingkungan sekitar termasuk budaya yang majemuk (Rahmatullah, Inanna, \& Nurdiana, 2019). Dalam pendidikan keluarga penting adanya pemahaman mendasar mengenai pengelolaan uang saku sejak dini sehingga menjadi suatu kebiasaan (Lewis \& Scott, 2000).

Disadari atau tidak, di zaman milenial ini, mahasiswa sebagai bagian dari anggota keluarga telah mengalami proses perubahan dalam aktivitas konsumsinya, dengan banyaknya pilihan kebutuhannya terkadang sulit membuat keputusan yang rasional sehingga mahasiswa tidak dapat membedakan antara kebutuhan dan keinginan berdasarkan prinsip ekonomi. Perubahan aktivitas konsumsi mahasiswa dipengaruhi oleh faktor internal dan eksternal. Hasil penelitian Hastuti, Sri., Padmawati, Mira Yuliana., Harsono (2019; 88), menjelaskan bahwa perubahan setiap mahasiswa dari perilakunya, kebiasaannya, fashion yang digunakan, aktivitasnya serta 
minat akan sesuatu dipengaruhi oleh beberapa faktor yaitu faktor eksternal dan internal.

Faktor eksternal melalui media massa, pergaulan dan gaya hidup terkadang menjadikan seseorang melupakan rasionalitasnya dalam melakukan tindakan ekonomi sehingga menimbulkan perilaku konsumtif, yaitu adanya keinginan seseorang untuk memperoleh atau membeli barangbarang yang tidak dibutuhkan. Selain faktor eksternal, faktor paling dominan tentu saja dalam lingkungan keluarga. Perilaku ekonomi anak sebagian besar diterima dalam lingkungan keluarga, sejak anak-anak, mereka telah menerima transfer of knowledge dalam keluarga tentang sikap berekonomi yang rasional, yaitu membeli dengan mengedepankan kebutuhan bukan pada keinginan, sehingga kesejahteraan dapat direalisasikan baik ketika mereka masih tinggal bersama orang tua maupun ketika mereka sudah jauh dari keluarga. Pendidikan informal adalah jalur pendidikan keluarga dan lingkungan. Kegiatan pendidikan informal dilakukan oleh keluarga dan lingkungan dalam bentuk kegiatan belajar secara mandiri (Inanna, 2018).

Pendidikan ekonomi informal mempunyai peran yang sangat penting dalam mewujudkan perilaku ekonomi anak yang rasional. Sebab pendidikan di dalam keluarga merupakan pendidikan pertama dan utama bagi seseorang dalam pembentukan karakter seseorang terutama karakter ekonominya.

Pendidikan ekonomi informal dapat diberikan melalui pembiasaan, keteladanan, dan penjelasan terkait aktivitas ekonomi. Pendidikan ekonomi informal lebih bersifat pembiasaan, maka prosesnya lebih banyak menuntut keteladanan dan pengalaman nyata dalam kehidupan sehari-hari (Wahyono, 2001). Dengan pembiasaan, keteladanan, dan penjelasan akan membentuk pola sikap dan pola tindak sebagai wujud dari perilaku dalam hal berkonsumsi.

Transfer of knowledge dalam pendidikan informal difokuskan pada pemahaman dasar tentang tata cara berperilaku khususnya dalam mengatur sumberdaya sesuai dengan prinsip ekonomi yang rasional melalui pembiasaan, keteladanan serta penjelasan. Pendidikan ekonomi informal dapat dilakukan dengan membiasakan mengelola keuangan dengan cara membelanjakan sesuai dengan kebutuhan, menghemat uang dengan cara menabung, dan menginvestasikan uang dengan benar.

Pendidikan informal yang dilakukan dengan contoh pembiasaan kepada anak akan menciptakan perilaku anak yang rasional dalam melakukan aktivitas ekonominya, yaitu anak akan melakukan pengambilan keputusan berdasarkan akal sehat dan menguntungkan. Terutama dalam hal aktivitas konsumsi yang dilakukan sehari-hari. Pengalaman yang diperoleh anak melalui pendidikan dalam keluarga akan mempengaruhi perkembangan anak dalam proses pendidikan selanjutnya, (Inanna, Rahmatullah, Haeruddin, \& Marhawati, 2020).

Mahasiswa sebagai salah satu pelaku kegiatan ekonomi menjadi sasaran utama pasar. Mereka cenderung terpengaruh dan bertindak emoisonal dalam perilaku konsumtif, hal ini didasarkan karena cenderung mengikuti perkembangan yang selalu berubah. Oleh karena itu, peran keluarga sangat penting bagi seseorang dalam melakukan aktifitas ekonominya.

Keluarga yang selalu berlaku rasional dalam melakukan kegiatan ekonominya khususnya dalam aktivitas konsumsinya, selalu membelanjakan keuangan mereka sesuai dengan kebutuhan dalam rumah tangga akan menjadi modal yang akan dijadikan panutan anak-anak mereka dalam menjalankan kehidupannya di masa mendatang, pembiasaan yang sering terjadi dalam lingkungan keluarga dalam pemenuhan kebutuhan secara rasional akan mempunyai pengaruh terhadap perilaku ekonomi anak dalam kehidupan ekonomi yang penuh dengan tantangan. Dengan demikian perlu dilakukan sebuah penelitian tentang pentingnya pendidikan ekonomi informal dalam mewujudkan perilaku ekonomi mahasiswa yang rasional.

Tujuan penelitian ini adaah untuk mengetahui pengaruh pendidikan yang diberikan orang tua dalam mewujudkan perilaku ekonomi mahasiswa yang rasional melalui tingkah laku sehari-hari yang dicontohkan orang tua dalam lingkungan keluarga mahasiswa pendidikan ekonomi Universitas Negeri Makassar.

\section{METODE PENELITIAN}

Penelitian ini menggunakan pendekatan kuantitatif dengan tujuan untuk 
mengetahui pengaruh pendidikan ekonomi informal dalam mewujudkan perilaku ekonomi yang rasional pada mahasiswa pendidikan ekonomi Universitas Negeri Makassar. Variabel dalam penelitian ini adalah pendidikan ekonomi informal (X1) dan perilaku rasionalitas ekonomi mahasiswa (Y).

Populasi dalam penelitian ini adalah mahasiswa program studi pendidikan ekonomi Universitas Negeri Makassar sebanyak 659 orang, Adapun sampel sebanyak 70 mahasiswa. Teknik pengambilan sampel adalah proportional random sampling. Teknik pengumpulan data adalah observasi, angket, dan dokumentasi. Teknik analisis data yang digunakan adalah analisis regresi linear sederhana.

\section{HASIL DAN PEMBAHASAN}

Hasil penelitian terhadap mahasiswa pendidikan ekonomi Universitas Negeri Makassar menunjukkan bahwa proses pendidikan ekonomi informal yang berlangsung dalam keluarga mahasiswa menjadi dasar bagi mereka dalam melakukan aktivitas konsumsinya sehari-hari, Orang tua secara kontinu memberikan pembiasaan kepada anak berupa kemandirian, tanggung jawab dan melatih untuk menahan diri terhadap keinginan yang tidak terbatas. Orang tua melatih untuk hidup hemat kepada anaknya (mahasiswa) dan menanamkan sifat kedisiplinan dalam mengeluarkan uang sesuai dengan kebutuhan. Orang tua meyakinkan kepada anak (mahasiswa) akan tanggung jawab yang besar dalam membelanjakan uang dan menumbuhkan kepercayaan kepada anak dalam mengelola uang saku mereka. Hasil penelitian menunjukkan, orang tua memberikan kepercayaan sepenuhnya kepada anak mereka untuk mengelola uang saku sendiri dan memberikan penjelasan untuk berhati-hati menggunakan uang saku sesuai dengan kebutuhannya sehingga tertanam sifat kemandirian pada diri anak dalam melakukan aktivitas konsumtifnya.

Hasil persentase dengan indikator pembiasaan adalah $86,88 \% \quad 86,24 \%$ yang tergolong sangat baik. Hal tersebut menunjukkan bahwa orang tua telah memberikan pembiasaan yang baik terhadap anaknya terkait perilaku konsumsi sehari-hari.

Hasil persentase dengan indikator keteladanan adalah $86,24 \%$ yang tergolong baik. Hal tersebut menunjukkan bahwa orang tua atau anggota keluarga lainnya telah memberikan contoh keteladanan yang baik sebagai panutan bagi anaknya.

Hasil persentase dengan indikator penjelasan (transfer of knowledge) adalah $82,33 \%$ yang tergolong baik. Hal tersebut menunjukkan bahwa orang tua atau anggota keluarga lainnya telah memberikan penjelasan yang baik dab mudah dipahami terhadap anaknya terkait permasalahan ekonomi.

Secara keseluruhan, dari hasil penelitian yang telah dilakukan, indikator pembiasaan memberikan pengaruh paling besar dibandingkan dengan indikator keteladanan dan penjelasan. Hal tersebut berarti bahwa pembiasaan yang dilakukan oleh orang tua dengan memberikan contoh langsung kepada anaknya sangat berpengaruh, salah satu contoh adalah pembiasaan untuk hidup hemat dengan cara menabung dan bertanggung jawab dalam mengelola uang sau sendiri.

Peran orang tua mahasiswa melalui pembiasaan hidup hemat serta pembelian barang sesuai kebutuhan akan berpengaruh terhadap pola tindak dalam konsumsinya. Dengan penanaman nilai-nilai ekonomi dalam keluarga yang baik akan terbentuk perilaku yang baik pula serta akan membentuk mahasiswa untuk memiliki karakter ekonomi yang rasional.

Hasil penelitian yang telah dilakukan, sebagian besar mahasiswa pendidikan ekonomi Universitas Negeri Makassar yang telah memperoleh pendidikan ekonomi informal telah menerapkannya dalam kehidupan sehari-hari baik di lingkungan kampus maupun di lingkungan tempat tinggal mereka. Setiap mahasiswa akan melakukan aktivitas konsumsinya, mereka melakukan konsumsi sesuai dengan kebiasaan serta keteladanan yang diperoleh dalam llingkungan keluarga mereka. Dapat disimpulkan bahwa pendidikan ekonomi dalam keluarga mahasiswa akan sangat berpengaruh terhadap rasionalitas ekonomi mereka.

\section{KESIMPULAN DAN SARAN}

Berdasarkan pembahasan yang telah diuraikan maka dapat disimpulkan bahwa Pendidikan Ekonomi informal sangat penting diberikan untuk mewujudkan perilaku ekonomi Mahasiswa yang rasional. Temuan pada penelitian ini menunjukkan bahwa indikator 
pembiasaan, memberikan pengaruh yang besar dalam mewujudkan perilaku ekonomi mahasiswa yang rasional, walaupun model pembiasaan setiap keluarga bervariasi.

Mahasiswa perlu dibekali dengan pola pembiasaan, keteladan dan penjelasan terkait dengan kegiatan ekonomi, baik aktivitas konsumsi, produksi dan distribusi dalam lingkungan keluarga sebagai suatu alternatif dalam mewujudkan perilaku mahasiswa yang rasional dalam berekonomi.

\section{DAFTAR RUJUKAN}

Hastuti, Sri., Padmawati, Mira Yuliana., Harsono, H. 2019. Literasi Ekonomi dan Gaya Hidup Mahasiswa. ISSN-25034855.Seminar Nasional Pendidikan IV, Pendidikan Akuntansi FKIP UMS

Inanna, I. (2018). Peran Pendidikan Dalam Membangun Karakter Bangsa Yang Bermoral. JEKPEND" Jurnal Ekonomi Dan Pendidikan", 1(1), 27-33.

Inanna, I., Rahmatullah, R., Haeruddin, M. I. M., \& Marhawati, M. (2020). Silk Weaving as a Cultural Heritage in the Informal Entrepreneurship Education Perspective. 23(1), 1-11.

Lermitte, Paul. W. Merritt. J. 2004. Making Allowace System, Agar Anak Pandai Mengelola Keuangan. Terjemahan Lina Bundaran. Jakarta: PT. Gramedia Pustaka Utama

Lewis, A., \& Scott, A. J. (2000). The Economic Awareness, Knowledge and Pocket Money Practices of a Sample of UK Adolescents: A Study of Economic Socialisation and Economic Psychology. Citizenship, Social and Economics Education, 4(1), 34-46. https://doi.org/10.2304/csee.2000.4.1.34

Mintarti, Sri Umi. Analisis Pendidikan Keuangan dalam Keluarga, Dalam Membentuk Sikap Berekonomi Yang Rasional. 2014. Prosiding Pluralisme Dalam Ekonomi dan Pendidikan. ISSN 2407-2468. Jurusan Ekonomi Pembangunan Fakultas Ekonomi Universitas Negeri Malang.

Požgaj, Ž. (2008). Informal learning in lifelong education. MIPRO 2008 - 31st International Convention Proceedings: Computers in Education, 4, 274-278.

Rahmatullah, R., Inanna, I., \& Nurdiana, N. (2019). Ethnopedagogi dalam pembelajaran ekonomi. Seminar Nasional Lembaga Penelitian UNM, 284-288.

Suprapti, Sri Ni Wayan. 2010. Perilaku konsumen pemahaman dasar dan aplikasinya dalam strategi pemasaran. Denpasar: Udayana University Press Suyanto, Bagong. (2013). Sosiologi Ekonomi. Jakarta: Kencana

Vito, Ishak. 2013. Pengaruh Pendidikan Ekonomi di Lingkungan Keluarga Terhadap Rasionalitas Ekonomi Mahasiswa Pendidikan Ekonomi Fkip Universitas Tanjung Pura. Jurnal Pendidikan dan Pembelajaran Volume 2 No. 6 Juni 2013

Wahyono, Hary. 2001. Pengaruh Perilaku Ekonomi kepala keluarga terhadapIntensitas Pendidikan Ekonomi di Lingkungan Keluarga. Disertasi tidak diterbitkan. Malang: PPS UM 